\title{
Co-production of gallic acid and a novel cell-associated tannase by a pigment-producing yeast, Sporidiobolus ruineniae A45.2
}

Apinun Kanpiengjai ${ }^{1,3^{*}}$ (D), Chartchai Khanongnuch ${ }^{2,3}$, Saisamorn Lumyong ${ }^{4}$, Dietmar Haltrich ${ }^{5}$,

Thu-Ha Nguyen ${ }^{5}$ and Suwapat Kittibunchakul ${ }^{5,6}$

\begin{abstract}
Background: Gallic acid has received a significant amount of interest for its biological properties. Thus, there have been recent attempts to apply this substance in various industries and in particular the feed industry. As opposed to yeasts, fungi and bacteria and their tannases have been well documented for their potential bioconversion and specifically for the biotransformation of tannic acid to gallic acid. In this research, Sporidiobolus ruineniae A45.2 is introduced as a newly pigment-producing and tannase-producing yeast that has gained great interest for its use as an additive in animal feed. However, there is a lack of information on the efficacy of gallic acid production from tannic acid and the relevant tannase properties. The objective of this research study is to optimize the medium composition and conditions for the co-production of gallic acid from tannic acid and tannase with a focus on developing an integrated production strategy for its application as a feed additive.
\end{abstract}

Results: Tannase produced by S. ruineniae A45.2 has been classified as a cell-associated tannase (CAT). Co-production of gallic acid obtained from tannic acid and CAT by S. ruineniae A45.2 was optimized using response surface methodology and then validated with the synthesis of $11.2 \mathrm{~g} / \mathrm{L}$ gallic acid from $12.3 \mathrm{~g} / \mathrm{L}$ tannic acid and the production of $31.1 \mathrm{mU} / \mathrm{mL}$ CAT after $48 \mathrm{~h}$ of cultivation in a 1-L stirred tank fermenter. Tannase was isolated from the cell wall, purified and characterized in comparison with its native form (CAT). The purified enzyme (PT) revealed the same range of $\mathrm{pH}$ and temperature optima ( $\mathrm{pH}$ ) as $\mathrm{CAT}$ but was distinctively less stable. Specifically, CAT was stable at up to $70^{\circ} \mathrm{C}$ for $60 \mathrm{~min}$, and active under its optimal conditions $\left(40^{\circ} \mathrm{C}\right)$ at up to 8 runs.

Conclusion: Co-production of gallic acid and CAT is considered an integrated and green production strategy. S. ruineniae biomass could be promoted as an alternative source of carotenoids and tannase. Thus, the biomass, in combination with gallic acid that was formed in the fermentation medium, could be directly used as a feed additive. On the other hand, gallic acid could be isolated and purified for food and pharmaceutical applications. This paper is the first of its kind to report that the CAT obtained from yeast can be resistant to high temperatures of up to $70^{\circ} \mathrm{C}$.

Keywords: Tannase, Tannins, Gallic acid, Yeast, Sporidiobolus ruineniae, Miang

*Correspondence: ak.apinun@gmail.com

${ }^{1}$ Division of Biochemistry and Biochemical Technology, Department

of Chemistry, Faculty of Science, Chiang Mai University, Chiang Mai 50200, Thailand

Full list of author information is available at the end of the article

\section{Background}

Gallic acid is a chemical constituent of the tannic acid molecules that are commonly found in tea leaves [1]. It has mainly been used in the pharmaceutical industry for the production of trimethoprim, an antibacterial agent, and gallate esters, that are used as preservatives in the food production industry [2]. However, gallic acid has

(c) The Author(s) 2020. This article is licensed under a Creative Commons Attribution 4.0 International License, which permits use, sharing, adaptation, distribution and reproduction in any medium or format, as long as you give appropriate credit to the original author(s) and the source, provide a link to the Creative Commons licence, and indicate if changes were made. The images or other third party material in this article are included in the article's Creative Commons licence, unless indicated otherwise in a credit line to the material. If material is not included in the article's Creative Commons licence and your intended use is not permitted by statutory regulation or exceeds the permitted use, you will need to obtain permission directly from the copyright holder. To view a copy of this licence, visit http://creativeco mmons.org/licenses/by/4.0/. The Creative Commons Public Domain Dedication waiver (http://creativecommons.org/publicdomain/ zero/1.0/) applies to the data made available in this article, unless otherwise stated in a credit line to the data. 
received a significant amount of interest in terms of its biological properties, particularly for its antioxidant, antibacterial, anticarcinogenic, antiallergic and antiinflammatory activities [3, 4]. The supplementation of gallic acid into broiler chick feed has improved the performance and jejunum intestinal morphology of broiler chicks [5]. Recent reports have revealed that proper minimum concentrations of gallic acid exhibit antimicrobial activity against human and animal pathogenic bacteria including Escherichia coli, Pseudomonas aeruginosa, Staphylococcus aureus, Listeria monocytogenes [6], and especially Campylobacter jejuni and C. coli [7]. Conventionally, acid hydrolysis of tannic acid is a method that is used to produce gallic acid, but it has some limitations in terms of its purity and yield [3]. Microbial and enzymatic conversions of tannic acid to gallic acid are attractive strategies for overcoming the drawbacks of the chemical method. Tannase catalyzes the hydrolysis of tannic acid to release glucose and gallic acid. It is primarily produced by bacteria and fungi as opposed to yeasts, from which its production has rarely been reported. Only Candida sp. [8] and Kluyveromyces marxianus [9], have been verified in terms of the ability to express tannases and the properties of their enzymes, but there is very little information on the bioconversion of tannic acid to gallic acid.

Animal feed additives are in fact one of the most interesting applications of tannase and gallic acid apart from its potential pharmaceutical and food applications. The addition of tannase in feed could decrease the antinutritional effect of tannins, thereby improving the digestibility of the feed and the degree of mineral absorption in animals [10]. Supplementation of gallic acid in feed mixtures has been reported to have significantly positive effects on the microbial community of animals $[6$, 7]. In a previous research, Sporidiobolus ruineniae A 45.2 was found to be one of the most promising tannin-tolerant and tannase-producing yeasts that was isolated from Miang, a fermented tea-leaf prevalent in northern Thailand [11]. Among its physiological and biochemical characteristics is the formation of a red pigment. Consequently, it is assumed to be a member of the carotenoid family as has been reported in previous studies $[12,13]$. Thus, S. ruineniae could be used in the production of gallic acid and biomass containing tannase activity and carotenoids, the latter having recognized health-promoting effects for both human and animals. The objective of this research study is to optimize the medium composition and conditions for the co-production of gallic acid obtained from tannic acid and tannase with a focus on developing an integrated production strategy for its applications as a feed additive. As this is the first report on tannase obtained from pigment-producing yeast, enzyme production and biochemical characterization were also included in this research study in order to evaluate its potential for further use.

\section{Results}

Bioconversion of tannic acid to gallic acid and tannase production by S. ruineniae A45.2

Sporidiobolus ruineniae A45.2 formed a clear zone around a red colony when grown on yeast malt agar (YMA) supplemented with tannic acid (Fig. 1). No tannase activity was detected in the culture medium when the yeast was cultivated in yeast malt broth
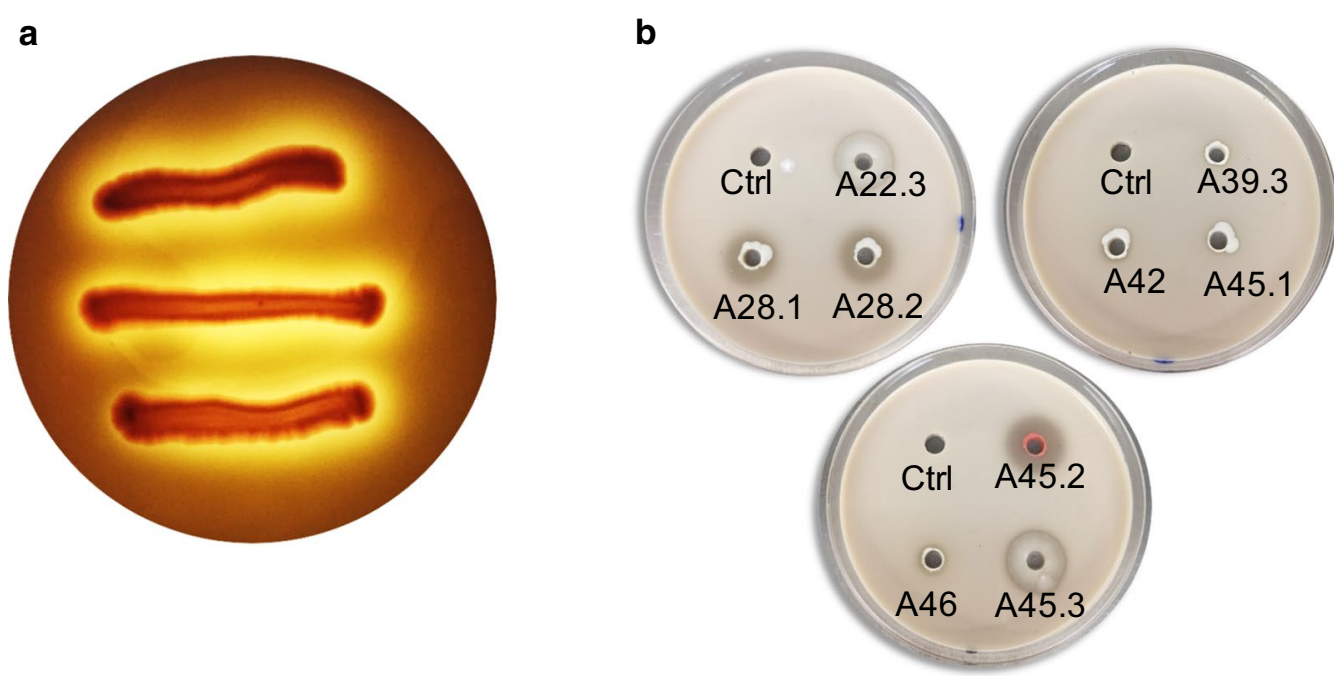

Fig. 1 Growth of S. ruineniae A45.2 on YMA supplemented with $10 \mathrm{~g} / \mathrm{L}$ tannic acid (a) and clear zone formation of nine tannin-tolerant yeast isolates on YMA supplemented with $10 \mathrm{~g} / \mathrm{L}$ tannic acid (b) after culturing at $30^{\circ} \mathrm{C}$ for 3 days 
(YMB) that was supplemented with $5 \mathrm{~g} / \mathrm{L}$ tannic acid, but $5.2 \pm 0.2 \mathrm{~g} / \mathrm{L}$ gallic acid was satisfactorily obtained. Evaluation of enzyme activity using a whole cell as a biocatalyst revealed activity of $0.5 \pm 0.06$ and $1.3 \pm 0.1 \mathrm{mU} / \mathrm{mL}$ after cultivation for $12 \mathrm{~h}$ and $24 \mathrm{~h}$, respectively (Table 1 ). The amount of activity detected in the soluble fraction was proportional to $50 \%$ of the whole cell implying that cell disruption could partly release enzymes from the cell wall. Here, tannase produced by S. ruineniae A45.2 was designated as a cellassociated tannase (CAT). However, enhancement of its co-production capabilities is of high relevance with regard to the need to establish the highest level of bioconversion tannic acid to gallic acid and CAT yields. As CAT is a cell surface-displayed enzyme, production of CAT may be associated with cell numbers. In statistical optimization, gallic acid, CAT and cell numbers are considered response variables of the co-production system.

Table 1 Tannase activity, gallic acid content and viable cell numbers of S. ruineniae A45.2 when cultivated in YMB supplemented with $5 \mathrm{~g} / \mathrm{L}$ tannic acid at $30^{\circ} \mathrm{C}$

\begin{tabular}{lll}
\hline Parameters & $\mathbf{1 2} \mathbf{h}$ & $\mathbf{2 4} \mathbf{h}$ \\
\hline Cell free supernatant $(\mathrm{mU} / \mathrm{mL})$ & 0 & 0 \\
Soluble fraction $(\mathrm{mU} / \mathrm{mL})$ & $0.25 \pm 0.06$ & $0.6 \pm 0.12$ \\
Cell-associated tannase $(\mathrm{mU} / \mathrm{mL})$ & $0.5 \pm 0.06$ & $1.3 \pm 0.10$ \\
Gallic acid (g/L) & $2.5 \pm 0.1$ & $5.2 \pm 0.2$ \\
Viable cells (logCFU/mL) & $6.95 \pm 0.03$ & $7.16 \pm 0.02$ \\
\hline
\end{tabular}

Optimization for co-production of gallic acid, CAT and viable cell numbers

Tannase produced by S. ruineniae A45.2 has been confirmed as an inducible enzyme that is naturally immobilized on the yeast cell surface (data not shown). Statistical optimization was used as a tool for the efficient co-production of gallic acid, CAT and cell number yields. Plackett and Burman design (PBD) was used to evaluate seven factors influencing the response variables as is shown in Table 2. Gallic acid content, CAT and cell numbers obtained from different compositions of media and incubation times based on the design matrix of PBD were assessed using analysis of variance (ANOVA) and the results are shown in Table 3 . The data obtained from the experiment (gallic acid content, CAT, and cell numbers) were well-fitted with the least square linear regression model according to the significance of the model fit value with the $R^{2}$-values and the adjusted $R^{2}$-values being higher than 0.95 . Tannic acid was the most significant variable that enhanced the production of gallic acid, CAT and viable cell numbers. Glucose had a significantly negative effect on the production of gallic acid and CAT, while it was positive in terms of viable cell numbers. Furthermore, there was a negative significant interaction between glucose and tannic acid that influenced cell numbers (data not shown). Basically, glucose is one of the most easily assimilated carbon sources for microbial growth. Tannic acid contains 10 galloyl units surrounding a glucose center. Therefore, it acts as an inducer for tannase production and a carbon source for cell growth.

Table 2 Experimental design matrix of PBD and response variables for screening of the most significant factors affecting co-production of gallic acid, CAT and viable cell numbers

\begin{tabular}{|c|c|c|c|c|c|c|c|c|c|c|}
\hline Run & $\begin{array}{l}\text { A:Tannic } \\
\text { acid (g/L) }\end{array}$ & B: Yeast (g/L) & $\begin{array}{l}\text { C: } \\
\text { Glucose } \\
\text { (g/L) }\end{array}$ & $\begin{array}{l}\mathrm{D}: \\
\left(\mathrm{NH}_{4}\right)_{2} \mathrm{SO}_{4} \\
(\mathrm{~g} / \mathrm{L})\end{array}$ & $\begin{array}{l}\text { E: } \\
\text { Tween80 } \\
\text { (g/L) }\end{array}$ & $\begin{array}{l}\text { F: } \\
\text { Glutamate } \\
\text { (g/L) }\end{array}$ & G: Time (h) & Gallic acid (g/L) & CAT (mU/mL) & $\begin{array}{l}\text { Viable cell } \\
\text { numbers } \\
\text { (logCFU/mL) }\end{array}$ \\
\hline 1 & 5 & 10 & 2 & 10 & 2 & 5 & 24 & 3.50 & 18.08 & 7.35 \\
\hline 2 & 1 & 10 & 10 & 2 & 2 & 5 & 24 & 0.23 & 3.81 & 7.58 \\
\hline 3 & 5 & 2 & 10 & 10 & 0.5 & 5 & 72 & 3.82 & 15.99 & 6.32 \\
\hline 4 & 1 & 10 & 2 & 10 & 2 & 1 & 72 & 0.18 & 0.00 & 4.70 \\
\hline 5 & 1 & 2 & 10 & 2 & 2 & 5 & 72 & 0.34 & 2.95 & 7.22 \\
\hline 6 & 1 & 2 & 2 & 10 & 0.5 & 5 & 24 & 1.09 & 13.56 & 6.96 \\
\hline 7 & 5 & 2 & 2 & 2 & 2 & 1 & 72 & 4.42 & 18.32 & 7.37 \\
\hline 8 & 5 & 10 & 2 & 2 & 0.5 & 5 & 72 & 4.99 & 19.70 & 7.45 \\
\hline 9 & 5 & 10 & 10 & 2 & 0.5 & 1 & 24 & 4.85 & 16.91 & 7.16 \\
\hline 10 & 1 & 10 & 10 & 10 & 0.5 & 1 & 72 & 0.46 & 5.32 & 6.64 \\
\hline 11 & 5 & 2 & 10 & 10 & 2 & 1 & 24 & 2.95 & 12.99 & 7.11 \\
\hline 12 & 1 & 2 & 2 & 2 & 0.5 & 1 & 24 & 1.06 & 13.55 & 7.08 \\
\hline 13 & 3 & 6 & 6 & 6 & 1.25 & 3 & 48 & 2.57 & 18.71 & 7.87 \\
\hline 14 & 3 & 6 & 6 & 6 & 1.25 & 3 & 48 & 2.65 & 19.68 & 7.93 \\
\hline 15 & 3 & 6 & 6 & 6 & 1.25 & 3 & 48 & 2.64 & 16.68 & 7.75 \\
\hline
\end{tabular}


Table 3 Regression of coefficients and analysis of variance (ANOVA) of the first order model for response variables in PBD

\begin{tabular}{|c|c|c|c|c|c|c|}
\hline \multirow[t]{3}{*}{ Source } & \multicolumn{2}{|l|}{ Gallic acid } & \multicolumn{2}{|l|}{ CAT } & \multicolumn{2}{|c|}{ Viable cell numbers } \\
\hline & Coefficient & p-value & Coefficient & p-value & Coefficient & $p$-value \\
\hline & Estimate & Prob $>F$ & Estimate & Prob $>F$ & Estimate & Prob $>F$ \\
\hline Model & 2.32 & $<0.0001$ & 11.7641 & 0.0011 & 6.91 & 0.0006 \\
\hline A-Tannic acid & 1.76 & $<0.0001^{*}$ & 5.2333 & $<0.0001^{*}$ & 0.21 & $0.0047^{*}$ \\
\hline B-Yeast extract & 0.045 & 0.5695 & -1.1269 & 0.0921 & -0.31 & 0.0015 \\
\hline C-Glucose & -0.22 & $0.0273^{*}$ & -2.1026 & $0.0097^{*}$ & 0.09 & $0.0879^{*}$ \\
\hline $\mathrm{D}-\left(\mathrm{NH}_{4}\right)_{2} \mathrm{SO}_{4}$ & -0.32 & 0.0047 & -0.7756 & 0.2173 & -0.18 & 0.0137 \\
\hline E-Tween80 & -0.39 & 0.0020 & -2.4072 & 0.0052 & -0.24 & 0.0049 \\
\hline F-Glutamate & 3.30E-03 & 0.9658 & 0.5835 & 0.3398 & 0.02 & 0.6723 \\
\hline G-Time & 0.045 & 0.5695 & -1.3847 & 0.0491 & -0.51 & $0.0002^{*}$ \\
\hline
\end{tabular}

Gallic acid production: $\mathrm{R}^{2}=0.9823$, Adj- $\mathrm{R}^{2}=0.9541, \%$ C.V. $=2.17$, lack of fit $=0.0182$

CAT production: $R^{2}=0.9904$, Adj- $R^{2}=0.9737, \% C . V .=10.78$, lack of fit $=0.2074$

Viable cell production: $R^{2}=0.9564$, Adj- $R^{2}=0.9056, \% C . V .=11.91$, lack of fit $=0.0019$

* Significant difference at $p<0.05$

In the presence of tannic acid in the culture medium, sufficient supplementation of glucose seems to promote viable cell production rather than tannase and gallic acid productions. This is because yeast can more easily assimilate glucose in the culture medium than glucose that is derived from the degradation of tannic acid. Therefore, adequate amounts of glucose in the culture medium might be preferable to cell growth rather than tannase production. A reduction in enzyme production consequently affects gallic acid synthesis. Tannic acid was selected as the most significant variable that enhanced the co-production of gallic acid, CAT and cell numbers. In addition, glucose was selected in order to determine its effect on co-production, and at the same time to find an optimal concentration for the production process. Other variables were fixed at their low or high levels with regard to their effects and their relevant significant differences $\left(10 \mathrm{~g} / \mathrm{L}\right.$ yeast extract, $2 \mathrm{~g} / \mathrm{L}\left(\mathrm{NH}_{4}\right)_{2} \mathrm{SO}_{4}, 0.5 \mathrm{~g} / \mathrm{L}$ tween 80 and $1 \mathrm{~g} / \mathrm{L}$ glutamate, and $48 \mathrm{~h}$ cultivation time).

In central composite design (CCD) optimization, the ANOVA results revealed that tannic acid (A) at a broader range of concentrations than that of PBD had a significant effect on gallic acid production, CAT and cell numbers, while glucose (B) showed insignificantly positive effects on all response variables. Tannic acid was a positive significant factor for gallic acid production due to the fact that it is the dependent factor for gallic acid production. However, it was a negative factor for cell and CAT production, explaining that at high concentrations of tannic acid, the growth of $S$. ruineniae was partially inhibited and enzyme production was decreased. Tannic acid is generally considered to be a microbial inhibitor. Although S. ruineniae is classified as a tannin-tolerant yeast that is similar to other microorganisms, particularly filamentous fungi, excessively high concentrations of tannic acid could be a factor in inhibiting its growth. The growth of Aureobasidium pullulans DBS66 was maximized when cultured in basal medium containing $10 \mathrm{~g} / \mathrm{L}$ tannic acid and dramatically decreased in culture containing $20 \mathrm{~g} / \mathrm{L}$ tannic acid [14]. This outcome was also observed for tannase production by Bacillus licheniformis [15]. Low production yields of tannase under high tannic acid concentrations can be explained in terms of tannase synthesis. Because of the deposition of gallic acid on the cell surface, increases in tannic acid concentrations induced an increase in the tannase synthesis of Aspergillus awamori followed by an eventual decrease [16]. Additionally, tannic acid-glucose interaction (AB) was significant at a $p$-value of less than 0.25 . The second-order equations for co-production of gallic acid, CAT and viable cell numbers are given as follows:

$$
\begin{aligned}
& \text { Gallic acid }(\mathrm{g} / \mathrm{L})=-6.6112+2.2429 \mathrm{~A}+0.7194 \mathrm{~B}-0.0023 \mathrm{AB}-0.0731 \mathrm{~A}^{2}-0.0322 \mathrm{~B}^{2} \\
& \text { CAT }(\mathrm{mU} / \mathrm{mL})=21.8252+1.0411 \mathrm{~A}+2.5196 \mathrm{~B}+0.0574 \mathrm{AB}-0.1059 \mathrm{~A}^{2}-0.2319 \mathrm{~B}^{2}
\end{aligned}
$$

Cell numbers $(\log \mathrm{CFU} / \mathrm{mL})=7.8692+0.0985 \mathrm{~A}-0.0340 \mathrm{~B}+0.0034 \mathrm{AB}-0.0085 \mathrm{~A}^{2}-0.0007 \mathrm{~B}^{2}$ 

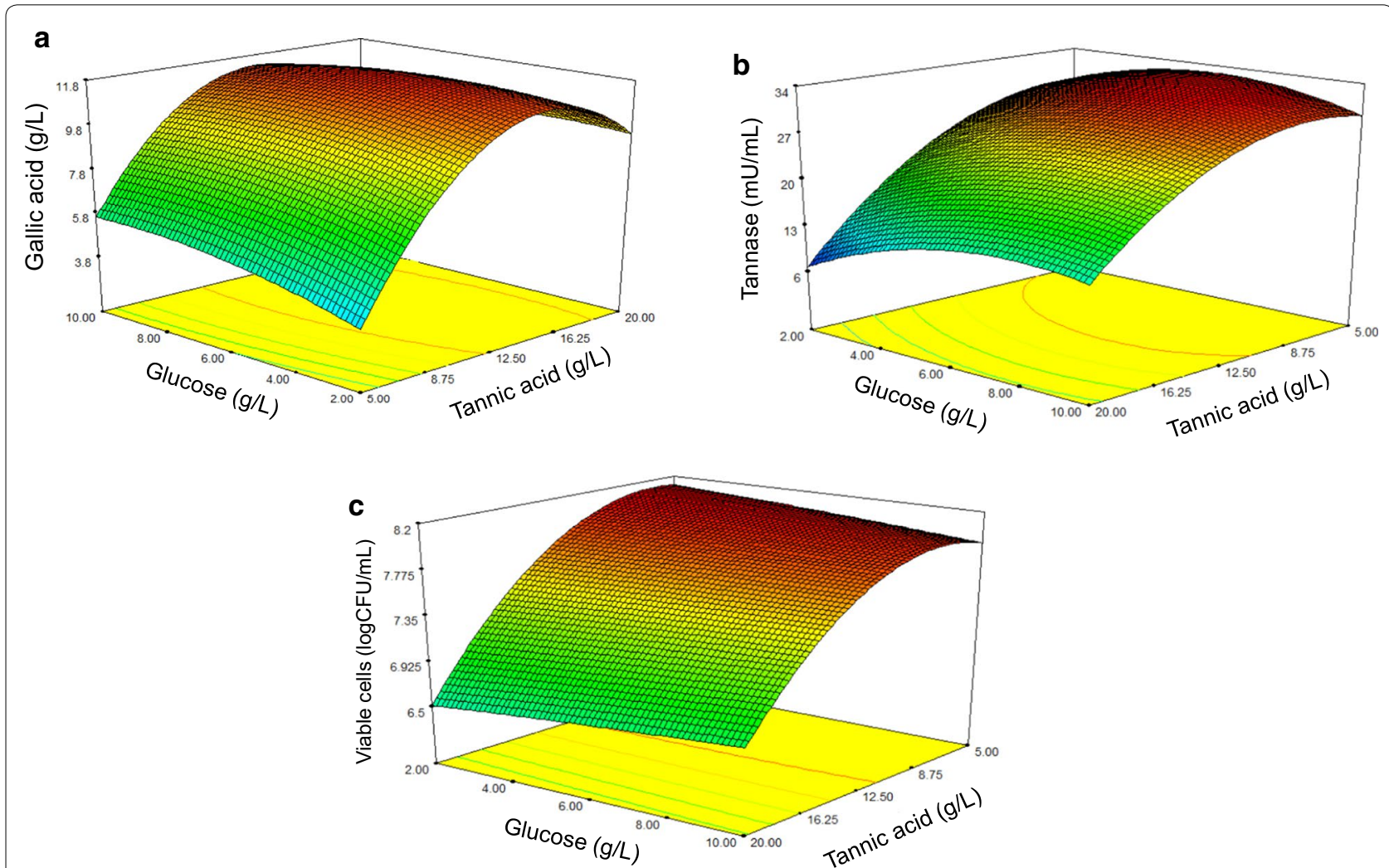

Fig. 2 Three-dimensional curves and contour plots demonstrating the effect of glucose and tannic acid on gallic acid production (a), tannase (b) and viable cells (c)

Table 4 Regression of coefficients and ANOVA of the second order polynomial model for response variables in CCD

\begin{tabular}{|c|c|c|c|c|c|c|}
\hline \multirow[t]{2}{*}{ Source } & \multicolumn{2}{|l|}{ Gallic acid } & \multicolumn{2}{|l|}{ CAT } & \multicolumn{2}{|c|}{ Viable cell numbers } \\
\hline & Coefficient & $p$-value & Coefficient & $p$-value & Coefficient & $p$-value \\
\hline Model & 11.49 & $<0.0001$ & 29.370 & 0.0001 & 7.804 & $<0.0001$ \\
\hline A-Tannic acid & 2.12 & 0.0003 & -9.460 & $<0.0001$ & -0.698 & $<0.0001$ \\
\hline B-Glucose & 0.21 & 0.5201 & 1.816 & 0.0962 & 0.003 & 0.9596 \\
\hline $\mathrm{AB}$ & -0.67 & 0.1774 & 1.721 & 0.2388 & 0.104 & 0.2245 \\
\hline$A^{2}$ & -4.11 & $<0.0001$ & -5.955 & 0.0006 & -0.478 & $<0.0001$ \\
\hline$B^{2}$ & -0.52 & 0.1712 & -3.711 & 0.0081 & -0.011 & 0.8541 \\
\hline Lack of fit & 0.0093 & & 0.0025 & & 0.0684 & \\
\hline$R^{2}$ & 0.9654 & & 0.9550 & & 0.9703 & \\
\hline Adjusted R2 & 0.9406 & & 0.9228 & & 0.9491 & \\
\hline Predicted $R^{2}$ & 0.7674 & & 0.6891 & & 0.8214 & \\
\hline
\end{tabular}

Regression models were employed to develop response surface plots as is shown in Fig. 2. These models produced acceptable results when $p<0.0001$ with $\mathrm{R}^{2}$-values and adjusted $\mathrm{R}^{2}$-values between 0.92 and 0.97 (Table 4). This indicated that up to $92-97 \%$ of the variations in gallic acid content, CAT and viable cell number can be explained by theses equations. The predicted values of
$11.46 \mathrm{~g} / \mathrm{L}$ for gallic acid, $7.82 \log \mathrm{CFU} / \mathrm{mL}$ for viable cells and $29.8 \mathrm{mU} / \mathrm{mL}$ (or $29.8 \mathrm{U} / \mathrm{L}$ ) for CAT were predicted from the models and successfully validated at $97 \%, 96 \%$ and $96 \%$, respectively when $12.32 \mathrm{~g} / \mathrm{L}$ tannic acid and $6.91 \mathrm{~g} / \mathrm{L}$ glucose were applied along with a considerable amount of other variables and conditions that have been previously described. Co-production in the 1-L 

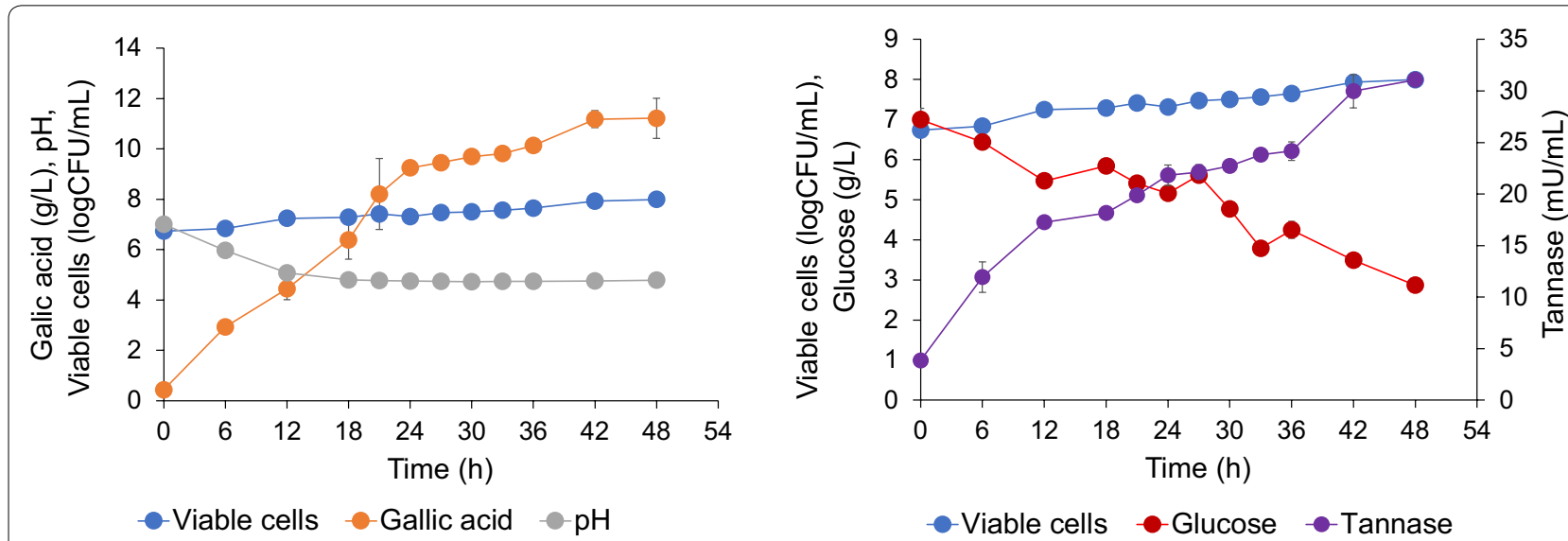

Fig. 3 Time course of batch fermentation for co-production of gallic acid, CAT and viable cells using optimized medium and conditions by S. ruineniae A45.2 in 1-L fermenter

fermenter (Fig. 3) confirmed that S. ruineniae A45.2 had potential in terms of the production of gallic acid, CAT and viable cell numbers due to maximal yields of $11.2 \mathrm{~g} / \mathrm{L}$ gallic acid (equivalent to $91 \%$ conversion or $0.91 \mathrm{~g}$ gallic acid/g tannic acid), $31.1 \mathrm{mU} / \mathrm{mL}$ CAT and $7.99 \operatorname{logCFU} /$ $\mathrm{mL}$ after $48 \mathrm{~h}$ of cultivation.

\section{Enzyme purification}

A total of $1950 \mathrm{mU}$ of tannase equivalent to $381 \mathrm{mU} /$ $\mathrm{mg}$ of protein was purified to homogeneity by applying the single-step process of Q-Sepharose anion-exchange chromatography. This yielded tannase that was purified 42.6-fold, with $62.3 \%$ recovery and a specific activity of $16,232 \mathrm{mU} / \mathrm{mg}$. The sodium dodecyl sulfate polyacrylamide gel electrophoresis (SDS-PAGE) (Fig. 4a) revealed a single band of approximately $89 \mathrm{kDa}$, whereas the molecular weight estimated by gel filtration chromatography was found to be approximately $172 \mathrm{kDa}$ (Fig. 4b).

\section{Characterization of purified tannase and CAT}

Purified tannase (PT) was biochemically characterized in comparison with CAT in order to determine any distinctive differences. CAT was active at $\mathrm{pH}$ values ranging from 4.0 to 9.0 with an optimal $\mathrm{pH}$ of 7.0 , while more than $80 \%$ relative activity was retained at $\mathrm{pH}$ values ranging from 8.0 to 9.0. These results were in accordance with those obtained from PT (Fig. 5a). For pH stability, both $\mathrm{PT}$ and CAT retained more than $80 \%$ of the original activity at $\mathrm{pH}$ values ranging from 5.0 to 9.0 , while CAT was slightly more stable at pH 5.0 (Fig. 5b). The effects of temperature on enzyme activity and stability were determined at temperatures ranging from 20 to $90{ }^{\circ} \mathrm{C}$. PT displayed the same range of optimal temperature as CAT since it showed the highest activity at $40^{\circ} \mathrm{C}$ (Fig. 5c). In terms of thermostability, PT was stable at 20 to $50{ }^{\circ} \mathrm{C}$ for $60 \mathrm{~min}$ without any loss in the original activity, and its stability tended to decrease at temperatures above $50^{\circ} \mathrm{C}$. CAT was
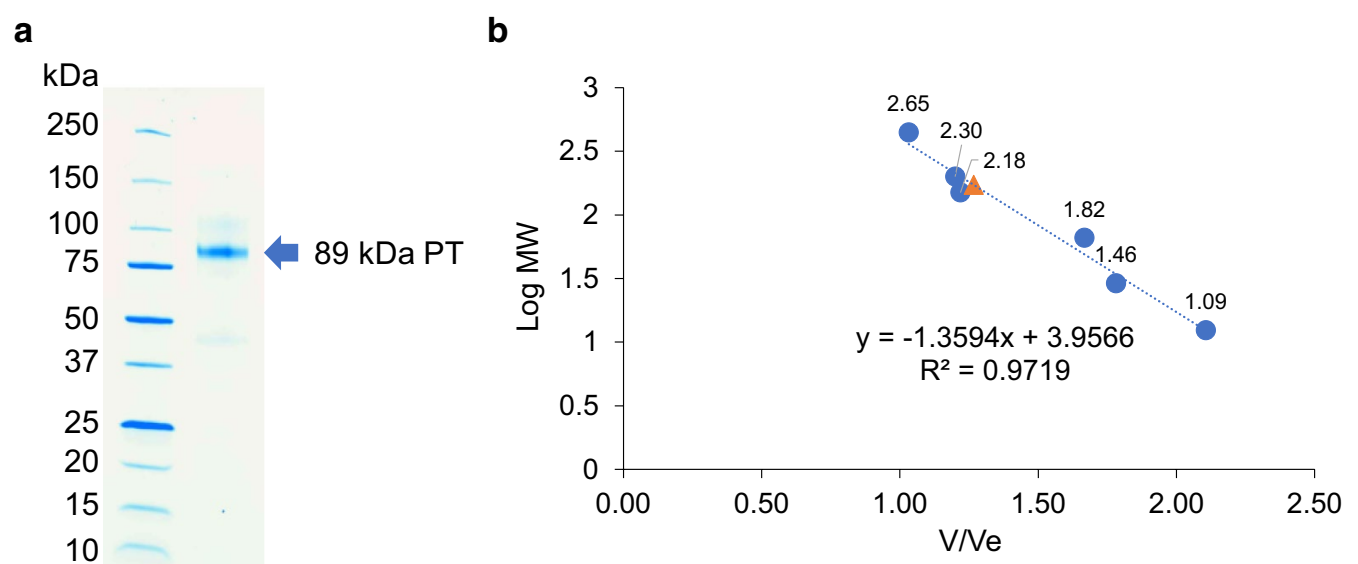

Fig. 4 Molecular weight determination of tannase by SDS-PAGE (a) and gel filtration chromatography (b) 

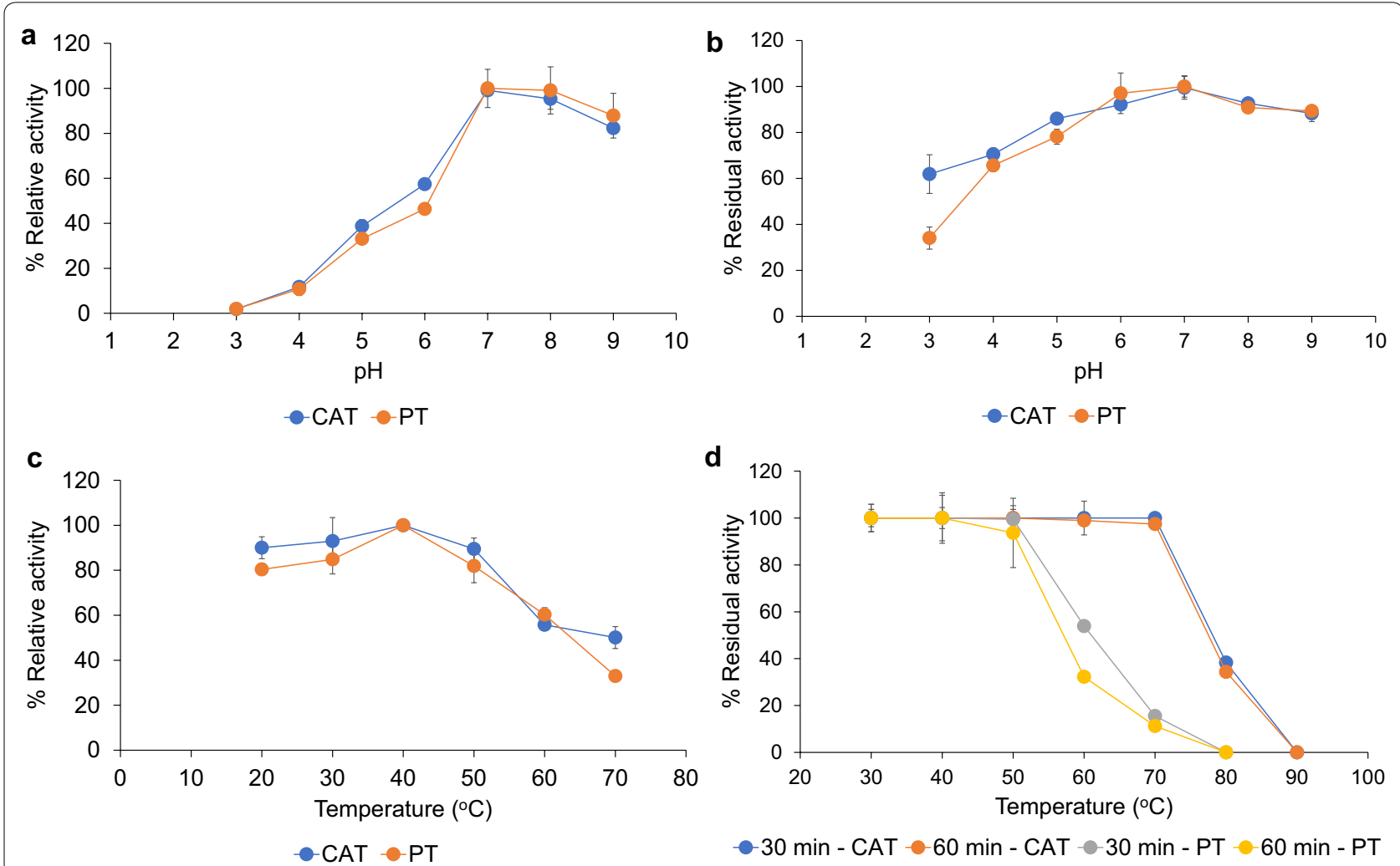

Fig. 5 Effect of pH on tannase activity (a), stability (b). Effect of temperature on tannase activity (c) and stability (d)

Table 5 Effect of various cations on CAT and PT activities

\begin{tabular}{lrr}
\hline Cation $\mathbf{( 5} \mathbf{~ m M})$ & \multicolumn{1}{l}{ CAT } & PT \\
\hline $\mathrm{Na}$ & $107.3 \pm 6.3$ & $100.1 \pm 8.8$ \\
$\mathrm{~K}$ & $107.3 \pm 6.3$ & $99.8 \pm 0.0$ \\
$\mathrm{Cu}$ & $60.7 \pm 0.0$ & $63.3 \pm 0.0$ \\
$\mathrm{Ca}$ & $107.3 \pm 6.3$ & $91.2 \pm 3.8$ \\
$\mathrm{Mg}$ & $103 \pm 5.5$ & $98.1 \pm 12.6$ \\
$\mathrm{Mn}$ & $116 \pm 3.5$ & $107.1 \pm 0.0$ \\
Control & $100.0 \pm 4.0$ & $100.0 \pm 4.6$ \\
\hline
\end{tabular}

more stable than PT as it retained $100 \%$ residual activity after being incubated at $30-70{ }^{\circ} \mathrm{C}$ for $60 \mathrm{~min}$ (Fig. $5 \mathrm{~d}$ ).

Both PT and CAT were not affected by $\mathrm{Na}^{+}, \mathrm{K}^{+}$, $\mathrm{Ca}^{2+}, \mathrm{Mg}^{2+}$ and $\mathrm{Mn}^{2+}$, but they were partially inhibited by $\mathrm{Cu}^{2+}$ as is shown in Table 5 . Under the same conditions, the relative measurement of the affinity of the methyl gallate revealed that PT and CAT exhibited similar $K_{\mathrm{m}}$ values of $2.6 \pm 0.4$ and $2.7 \pm 0.4 \mathrm{mM}$ and had $v_{\max }$ values of $583.5 \pm 12.3$ and $33.5 \pm 2.31(\mathrm{mU} / \mathrm{mL})$, respectively. Thus, CAT could not only act in the same manner as PT but was also determined to be active with a better level of thermostability.

\section{Repeatability of CAT}

CAT retained $100 \%$ relative gallic acid content after 8 runs of gallic acid production from methyl gallate under optimal conditions $\left(40{ }^{\circ} \mathrm{C}, \mathrm{pH} 7.0\right.$, and $30 \mathrm{~min}$ ), while $80 \%$ relative gallic acid content was retained afterwards (Fig. 6).

\section{Discussion}

Sporidiobolus ruineniae A45.2 is one of nine yeasts isolated from Miang that showed a positive result when using the visual reading method for detection of tannase activity in a previous study [11]. It was chosen for further characterization because it is a pigment-producing yeast, a characteristic that can be useful for feed application. As reported $[17,18]$, the tannase producing capacity of S. ruineniae may increase its value for feed applications. In addition, bioconversion of tannic acid to gallic acid by yeast sources poses a significant challenge as compared to bacterial or fungal biotransformation due to the lack of information regarding to such processes. In this research study, although CAT was expressed in terms of milliunits $(\mathrm{mU})$, it clearly revealed a high degree of efficacy in terms of the bioconversion of tannic acid to gallic acid since a complete bioconversion of $5 \mathrm{~g} / \mathrm{L}$ tannic acid to gallic acid 


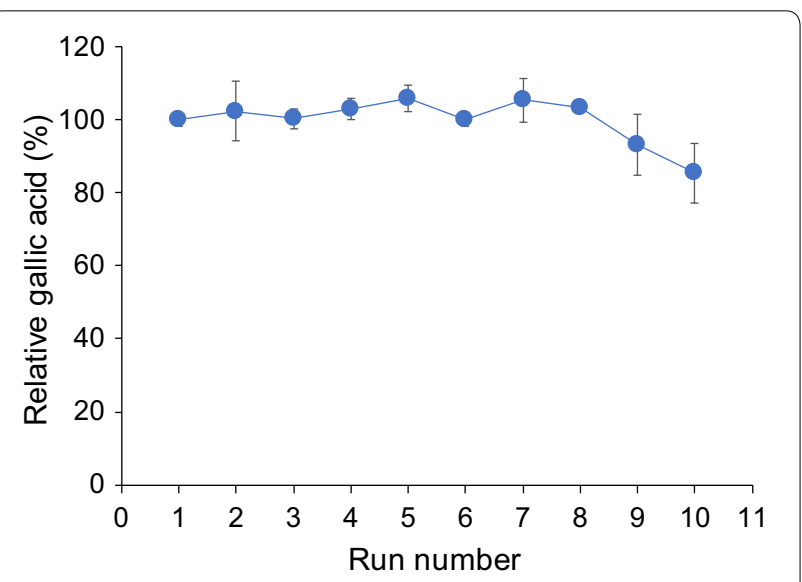

Fig. 6 Operational stability of CAT under repeated use

was found within $24 \mathrm{~h}$ of cultivation. Enhancement of coproduction by response surface methodology established the highest level of bioconversion, gallic acid production yields, viable cells and CAT in both a shake flask and a 1-L fermenter.

Candida sp. [8] and K. marxianus [9, 19] are the only two yeast species that are known to exhibit potential production of extracellular tannase; however, their potential for the bioconversion of tannic acid to gallic acid has not yet been evaluated. Although Aspergillus sp. was used for tannase production in several studies, gallic acid accumulation was not directly associated with its tannase yield, thus serving as only a tannase producer. An endogenous metabolism was a reason to explain the results $[20,21]$. This outcome is similar to the findings of experiments involving $B$. thurangiences $\mathrm{BN} 2$ [22] and $A u$. pullulans [14]. In contrast with the findings of this study, gallic acid, CAT and viable cells were greatly accumulated in the fermentation process until the end of the cultivation period. In terms of the bioconversion of tannic acid to gallic acid, $A$. niger Aa-20 produced $7.64 \mathrm{~g} / \mathrm{L}$ gallic acid from $12.5 \mathrm{~g} / \mathrm{L}$ tannic acid with a maximum tannase activity $2479 \mathrm{U} / \mathrm{L}$ in the optimized fermentation process [23]. Bioconversion of tannic acid to gallic acid by $A$. aculeatus DBF9 was optimized with a yield of $6 \mathrm{~g} / \mathrm{L}$ gallic acid from $30 \mathrm{~g} / \mathrm{L}$ tannic acid [21]. Recently, anaerobic fermentation of B. subtilis AM1 and Lactobacillus plantarum CIR1 in $10 \mathrm{~g} / \mathrm{L}$ tannic acid and under nonoptimized conditions resulted in the maximum levels of tannase activity at 1400 and $1239 \mathrm{U} / \mathrm{L}$ and gallic acid contents of 2.41 and $2.37 \mathrm{~g} / \mathrm{L}$, respectively [24]. In addition, the aforementioned tannases are enzymes secreted to the fermentation medium. To the best of our knowledge, CAT has not yet been identified in yeast. Recently CAT was found in Serratia facaria $[25,26]$ and B. massiliensis
[27], with activities corresponding to 9.65 and $0.56 \mathrm{mU} /$ $\mathrm{mL}$, respectively after optimization by RSM. The later strain of bacteria could enhance the formation of gallic acid from tea tannic acid with a maximum gallic acid production of approximately $0.475 \mathrm{~g} / \mathrm{L}$ when cultured under optimized conditions [28]. Considering the yields of gallic acid and tannase, S. ruineniae clearly revealed a greater potential for gallic acid $(11.8 \mathrm{~g} / \mathrm{L})$ and tannase $(29.8 \mathrm{mU} / \mathrm{mL})$ production.

Sporidiobolus ruineniae tannase was isolated from the cell wall, purified and biochemically characterized. This tannase has a molecular weight between 50 and $320 \mathrm{kDa}$, which is within the range of microbial tannases [29]. Based on the SDS-PAGE and gel filtration chromatography results, it is clearly suggested that CAT may be formed as a homodimeric enzyme with a molecular mass of approximately $180 \mathrm{kDa}$. Protein sequencing is required to assess $S$. ruineniae tannase identity. Depending on the type of microorganisms involved, tannases commonly consist of two or more units [29]. Recently, tannase obtained from $K$. marxianus was identified as having a monomeric state with a molecular weight of approximately $65 \mathrm{kDa}$ after determination by SDSPAGE [9], whereas tannase obtained from Candida sp. was a homodimeric enzyme with a molecular weight of $250 \mathrm{kDa}[8]$.

With the exception of thermostability, CAT and PT showed similar activity profiles at different $\mathrm{pH}$ and temperature ranges. They also displayed a $K_{\mathrm{m}}$ value that is in agreement with that of other reported yeast tannases. CAT and PT were not affected by most cations used in this study as tannases do not generally require a cofactor for their activity [29]. The extracellular enzyme obtained from $K$. marxianus had an optimal $\mathrm{pH}$ value of 4.5 and was stable at $\mathrm{pH}$ values between 4.0 and 4.5 without any loss in activity after being incubated under these conditions at $30{ }^{\circ} \mathrm{C}$ for $30 \mathrm{~min}$ [9], while the optimal $\mathrm{pH}$ of tannase from Candida sp. was recovered at a $\mathrm{pH}$ of 6.0 [8]. These results were distinctively different from those of PT and CAT. Most fungal tannases were optimally active at a $\mathrm{pH}$ value of around 6.0, whereas bacterial tannases were mostly active at $\mathrm{pH}$ values between 7.0 and 9.0 [29-31]. Furthermore, fungal tannases were stable at a broader range of $\mathrm{pH}$ than their bacterial counterpart [29]. Although CAT and PT displayed the same range of optimal $\mathrm{pH}$ as the bacterial tannases, they were more stable since more than $80 \%$ of residual activities were retained from $\mathrm{pH}$ values ranging from 5.0 to 9.0. Notably, CAT was stable at up to $70^{\circ} \mathrm{C}$ which was acknowledged as a broader range of temperature than $\mathrm{PT}$ and other reported yeast tannases $[8,9]$. The resistance of CAT to irreversible denaturalization at $30-70{ }^{\circ} \mathrm{C}$ is possibly related to this tannase being embedded in the cell 
wall, which may prevent complete or partial unfolding. With regard to previously reported findings, microbial tannases generally have temperature optima in a range of $20-60{ }^{\circ} \mathrm{C}$, and their thermostabilities are mainly between 30 and $60{ }^{\circ} \mathrm{C}$. In addition, fungal tannases are more active and stable than the bacterial and yeast tannases under various temperature conditions [29, 30]. Since thermostability usually limits industrial applications of enzymes, the tannase that is associated with the cells used in this study could be an alternative choice.

The use of CAT as an immobilized enzyme is of particular interest as it is present on the cell wall surface and could be used repeatedly. Immobilization provides a number of advantages beyond the ability to separate products and recover enzymes for recycling and thus minimizing downstream processing costs [32]. It is expected that $S$. ruineniae and CAT could be used with regard to free and immobilized cells for the biotransformation of tannic acid to gallic acid, which could then be beneficial in various applications.

From a practical point of view, CAT obtained from S. ruineniae A45.2 would be suitable for use in the feed industry, in which the addition of tannase can help in terms of feed digestibility and absorption. However, feed additive enzymes must be thermostable in order to withstand relevant conditioning and pelleting temperatures [33]. Gallic acid that is formed in the fermentation medium can be directly applied as a feed additive, or isolated and purified for food and pharmaceutical applications. In addition, S. ruineniae biomass can be used as a source of carotenoids and tannase for feed application.

\section{Conclusions}

This paper presents the first findings of CAT obtained from the pigment-producing yeast, Sporidiobolus ruineniae, which revealed a high degree of efficiency in terms of gallic acid production. It also exhibited viability in the presence of tannic acid after RSM optimization. CAT was more resistant to higher temperatures than the soluble tannase and exhibited similar biochemical properties. Consequently, it could be effectively employed in various applications and especially in the feed industry. The co-production of gallic acid, CAT and viable cells can be considered an integrated production strategy and can provide researchers with an opportunity to reduce costs associated with the process of downstream waste treatment.

\section{Methods}

\section{Microorganisms and culture conditions}

Sporidiobolus ruineniae A45.2 was grown on YMA (3 g/L yeast extract, $3 \mathrm{~g} / \mathrm{L}$ malt extract, $5 \mathrm{~g} / \mathrm{L}$ peptone, $10 \mathrm{~g} / \mathrm{L}$ glucose and $20 \mathrm{~g} / \mathrm{L}$ agar) that was supplemented with $5 \mathrm{~g} / \mathrm{L}$ tannic acid (prepared in $8 \mathrm{~g} / \mathrm{L} \mathrm{K}_{2} \mathrm{HPO}_{4}$ ) at $30{ }^{\circ} \mathrm{C}$ for $48 \mathrm{~h}$. Culturing was done in an Erlenmeyer flask at a temperature of $30^{\circ} \mathrm{C}$ with shaking at 150 -rpm. To prepare the seed inoculum, a loopful of S. ruineniae A45.2 was inoculated in YMB and incubated under the previously described culture conditions for $24 \mathrm{~h}$ or until the culture reached a maximal optical density at $600 \mathrm{~nm}\left(\mathrm{OD}_{600}\right)$ of $8-9$.

\section{Assay of tannase and determination of gallic acid}

Tannase and gallic acid content were assayed according to the method based on chromogen formation between gallic acid that was released from methyl gallate by a reaction of tannase and rhodanine (2-thio-ketothiazolidine) [34]. Briefly, the reaction mixture consisted of $50 \mu \mathrm{L}$ of an appropriately diluted enzyme solution in $100 \mathrm{mM}$ sodium-phosphate buffer $\mathrm{pH} 6.5$ and in $50 \mu \mathrm{L}$ of $12.5 \mathrm{mM}$ methyl gallate in the same buffer. The reaction mixture was carried out at $30^{\circ} \mathrm{C}$ and at $600 \mathrm{rpm}$ for $10 \mathrm{~min}$. To terminate the enzyme reaction and to determine gallic acid content, $60 \mu \mathrm{L}$ of $0.667 \%(\mathrm{w} / \mathrm{v})$ methanolic rhodanine solution was added to the mixture and it was left at room temperature $\left(20^{\circ} \mathrm{C}\right)$ for $5 \mathrm{~min}$. Subsequently, $40 \mu \mathrm{L}$ of $500 \mathrm{mM} \mathrm{KOH}$ was added to the mixture and it was left for $5 \mathrm{~min}$. Finally, $800 \mu \mathrm{L}$ of distilled water was added and the mixture was incubated at room temperature for $10 \mathrm{~min}$ prior to measuring the absorbance at $520 \mathrm{~nm}$. One unit of tannase activity was defined as the amount of the enzyme releasing $1 \mu$ mole of gallic acid per minute under assay conditions.

\section{Evaluation of gallic acid production} and tannase-producing ability by S. ruineniae A45.2 Sporidiobolus ruineniae A45.2 was grown on YMA supplemented with $5 \mathrm{~g} / \mathrm{L}$ tannic acid and incubated at $30{ }^{\circ} \mathrm{C}$. After $48 \mathrm{~h}$ of incubation, a clear zone formation was observed. To confirm and quantify the amount of tannase, $5 \mathrm{~mL}$ of seed inoculum was transferred to $25 \mathrm{~mL}$ of YMB supplemented with $5 \mathrm{~g} / \mathrm{L}$ of tannic acid. It was then incubated at $30{ }^{\circ} \mathrm{C}$ with shaking at $150-\mathrm{rpm}$. At $12 \mathrm{~h}$ and $24 \mathrm{~h}$ of cultivation, samples were collected for the measurement of viable cells using the spread plate technique, while a portion was centrifuged at $6000 \mathrm{rpm}$ at $4{ }^{\circ} \mathrm{C}$ for $20 \mathrm{~min}$. The supernatant was used as a crude extracellular enzyme. On the other hand, the obtained cell pellet was washed twice with $20 \mathrm{mM}$ sodium-phosphate buffer, $\mathrm{pH}$ 6.5 and resuspended in $10 \mathrm{~mL}$ of the same buffer. A half volume of the cell suspension was used as the whole cell tannase, while the rest was disrupted for 5 min using the Precellys 24 homogenizer (Bertin Technologies, France) in a bead beater. The resulting cell-free extract was designated as the soluble fraction. All fractions were assessed in terms of tannase activity by applying standard assay conditions. 


\section{Optimization}

PBD was used to screen and identify the most effective medium component and conditions for co-production of gallic acid and CAT. Based on the medium component that was reported for yeast tannase production [8] and live yeast cell production [35], a combination of seven factors including tannic acid, yeast extract, glucose, $\left(\mathrm{NH}_{4}\right)_{2} \mathrm{SO}_{4}$, glutamate and tween 80 were considered in preparation of the initial basal medium. Additionally, cultivation time was only considered a physical factor in the PBD experiment. Different media were prepared according to the design matrix of PBD (Table 2) that was created by Design Expert software version 7.0 (Stat-Ease Corporation, Minneapolis, USA). A total of $10 \%$ inoculum was transferred to the provided media and incubated under the standard culture conditions. Samples were collected in order to determine viable cell numbers, CAT and gallic acid content. ANOVA was used to evaluate the impact of a range of factors affecting the response variables. The factors whose $p$-values were less than 0.05 were considered significant factors and were further optimized by CCD.

In $C C D$, the five-level coded or actual values of each factor are represented by $-\alpha,-1,0,+1,+\alpha$ as is shown in Table 6, where $-1,+1$ correspond to the physical lower and upper limits of the explored factor space and $-\alpha,+\alpha$ correspond to the new extreme physical lower and upper limits for all factors. Different medium compositions were varied based upon the CCD matrix. The experiment was conducted under conditions that have been previously described. Samples were collected to determine viable cell numbers, CAT and gallic acid content. The achieved values were analyzed by ANOVA and regression analysis, and fitted to the quadratic model equation as follows:

$$
\mathrm{Y}=\beta_{0}+\sum \beta_{\mathrm{i}} \mathrm{x}_{\mathrm{i}}+\sum \beta_{\mathrm{ii}} \mathrm{x}_{\mathrm{i}}^{2}+\sum \beta_{\mathrm{ij}} \mathrm{x}_{\mathrm{i}} \mathrm{x}_{\mathrm{j}}
$$

where $Y$ is the predicted response variable; $x_{i}$ and $x_{j}$ are the independent variables of the experiment; $\beta_{0}$ is the intercept term; and $\beta_{\mathrm{i}}, \beta_{\mathrm{ii}}$ and $\beta_{\mathrm{ij}}$ are the linear, squared and interaction coefficients, respectively. Finally, the regression equation together with the 3D-plots were used to predict the optimal values of the independent factors for the highest viable cell numbers and the highest levels of CAT and gallic acid production. Furthermore, validation of the predicted values was performed to ensure quadratic model fitting.

\section{Co-production of gallic acid and CAT in 1-L fermenter}

To scale up the production of viable cells, CAT and gallic acid, the experiment was performed in a 1-L stirred tank fermenter (B.E. Marubishi Co Ltd., Tokyo, Japan) with a $60 \%$ working volume of the optimized medium. An inoculum of $10 \%(\mathrm{v} / \mathrm{v})$ was transferred to the fermenter with an agitation speed of $250 \mathrm{rpm}$ and an aeration rate of $0.2 \mathrm{vvm}$. The $\mathrm{pH}$ was not regulated during the cultivation process and the temperature was maintained at $30^{\circ} \mathrm{C}$. Samples were periodically collected in order to determine viable cells, CAT and gallic acid content.

\section{Preparation of CAT and enzyme purification}

Sporidiobolus ruineniae A45.2 was grown in 1-L fermenter for $48 \mathrm{~h}$ according to the method previously described. Cell pellets were harvested by centrifugation at $8000 \times g, 4{ }^{\circ} \mathrm{C}$ for $20 \mathrm{~min}$, washed twice with sodium

Table 6 Experimental design matrix of CCD and response variables for optimization of tannic acid and glucose concentrations

\begin{tabular}{llllll}
\hline Run & A: Tannic acid (g/L) & B: Glucose (g/L) & Gallic acid (g/L) & CAT (mU/mL) & $\begin{array}{l}\text { Viable cell numbers } \\
\text { (logCFU/mL) }\end{array}$ \\
\hline 1 & 5 & 2 & 2.78 & 29.90 & 7.94 \\
2 & 20 & 2 & 9.16 & 6.89 & 6.56 \\
3 & 5 & 10 & 4.51 & 26.18 & 7.72 \\
4 & 20 & 10 & 8.21 & 10.05 & 6.75 \\
5 & 1.89 & 6 & 1.54 & 31.82 & 8.06 \\
6 & 23.11 & 6 & 6.39 & 5.99 & 5.78 \\
7 & 12.5 & 0.34 & 10.83 & 18.06 & 7.83 \\
8 & 12.5 & 11.66 & 11.48 & 28.73 & 7.87 \\
9 & 12.5 & 6 & 11.96 & 28.77 & 7.88 \\
10 & 12.5 & 6 & 11.29 & 29.91 & 7.70 \\
11 & 12.5 & 6 & 11.62 & 28.66 & 7.81 \\
12 & 12.5 & 6 & 11.43 & 29.34 & 7.91 \\
13 & 12.5 & 6 & 11.15 & 30.18 & 7.72 \\
\hline
\end{tabular}


phosphate buffer $\mathrm{pH}$ 6.0, resuspended in the same buffer and used as CAT for the purposes of characterization. For the purposes of enzyme purification, the cell suspension was supplemented with $0.5 \%(\mathrm{w} / \mathrm{v})$ triton $\mathrm{X}-100$ as the final concentration. Cell suspension was agitated at $4{ }^{\circ} \mathrm{C}$ and $50 \mathrm{rpm}$ for $6 \mathrm{~h}$ before being centrifuged at $8000 \times g, 4{ }^{\circ} \mathrm{C}$ for $5 \mathrm{~min}$. The clear supernatant was collected and used for enzyme purification. Free tannase was applied onto a $20 \mathrm{~mL}$ Q-sepharose ${ }^{\mathrm{HP}}$ (GE Healthcare Bio-Sciences, Uppsala, Sweden) column that was equilibrated with $20 \mathrm{mM}$ of sodium phosphate buffer at $\mathrm{pH}$ 7.0. The tannase was eluted by a linear gradient of $0-1000 \mathrm{mM}$ of sodium chloride in $20 \mathrm{mM}$ of sodium phosphate buffer $\mathrm{pH} 7.0$ and with a flow rate of $0.5 \mathrm{~mL} / \mathrm{min}$. Active fractions were pooled and desalted using $10 \mathrm{kDa}$ cut-off Amicon Ultra Centrifugal filter tubes (Millipore, Bileria, MA, USA).

\section{Determination of protein concentration}

Protein concentrations were determined by the Bradford method using a protein assay system kit (BioRad, Hercules, CA, USA). Bovine serum albumin was used as a standard protein.

\section{Molecular weight determination}

SDS-PAGE were performed using Mini-PROTEAN ${ }^{\circledR}$ TGX Stain-Free Precast Gels (BioRad) according to the manufacturer's instructions. Determination conditions were carried out by heating the protein solution to $100{ }^{\circ} \mathrm{C}$ for $4 \mathrm{~min}$ prior to being loaded onto the SDSPAGE gel. Precision Plus Protein ${ }^{\mathrm{TM}}$ Standards (BioRad) was used as protein molecular mass markers. Protein bands were detected by being stained with Bio-Safe Coomassie (BioRad) according to the manufacturer's instructions.

For gel filtration chromatography, the purified enzyme was loaded onto a glass column $(60 \times 1.3 \mathrm{~cm})$ containing a Toyopearl HW-55 that was equilibrated with $20 \mathrm{mM}$ sodium phosphate $\mathrm{pH} 7.0$, and eluted with the same buffer at a flow rate of $0.25 \mathrm{~mL} / \mathrm{min}$. To calibrate the column, cytochrome $c(12.4 \mathrm{kDa})$, carbonic anhydrase $(29 \mathrm{kDa})$, bovine serum albumin $(66 \mathrm{kDa})$, alcohol dehydrogenase $(150 \mathrm{kDa}), \beta$-amylase $(200 \mathrm{kDa})$ and ferritin $(440 \mathrm{kDa})$ were used as the protein molecular weight standards. Blue dextran $(2000 \mathrm{kDa})$ was used to determine the void volume $\left(\mathrm{V}_{\mathrm{e}}\right)$.

\section{Effect of $\mathrm{pH}$ and temperature on enzyme activity and stability}

To determine the optimal $\mathrm{pH}$ values of $\mathrm{PT}$ and CAT, tannase activity $(36 \mathrm{mU})$ was assayed under standard conditions over a $\mathrm{pH}$ range of $3.0-9.0$. The buffers $(100 \mathrm{mM})$ used were citrate-phosphate for $\mathrm{pH}$ values in a range of
3.0-5.0, sodium phosphate buffer for $\mathrm{pH}$ values in a range of $6.0-7.0$ and Tris $-\mathrm{HCl}$ buffer for $\mathrm{pH}$ values in a range of 8.0-9.0. The $\mathrm{pH}$ stability of the enzyme was evaluated by incubating the enzyme at $37{ }^{\circ} \mathrm{C}$ at various $\mathrm{pH}$ values ranging from 3.0 to 9.0 in $20 \mathrm{mM}$ of the appropriate buffers for $6 \mathrm{~h}$. The activity without incubation was set to $100 \%$. Residual activity was determined under standard assay conditions. The optimum temperature was determined at temperatures ranging from 20 to $70{ }^{\circ} \mathrm{C}$ under standard assay conditions. In terms of thermostability, the enzyme was pre-incubated at various temperatures ranging from 30 to $90{ }^{\circ} \mathrm{C}$ for 30 and $60 \mathrm{~min}$. After that, it was placed on ice for 5 min prior to assaying the residual activity. The activity without incubation was set to $100 \%$.

\section{Effect of cations}

PT and CAT were assayed in the presence of $5 \mathrm{mM} \mathrm{Na}^{+}$, $\mathrm{K}^{+}, \mathrm{Ca}^{2+}, \mathrm{Cu}^{2+}, \mathrm{Mg}^{2+}$ and $\mathrm{Mn}^{2+}$ under otherwise standard assay conditions. Relative activities are provided and compared to those without cations.

\section{Determination of kinetic constants}

The $K_{\mathrm{m}}$ and $v_{\max }$ values of PT and CAT were determined using various concentrations of methyl gallate from 0.25 to $12.5 \mathrm{mM}$. The assay conditions were otherwise identical to the standard assay conditions. The experimental data were fitted to the Michaelis-Menten equation using SigmaPlot version 12.0 (Systat software, Inc., San Jose, CA, USA).

\section{Operational stability}

The operational stability of CAT was evaluated at its optimal $\mathrm{pH}$ value $(\mathrm{pH} 7.0)$ and temperature $\left(40{ }^{\circ} \mathrm{C}\right)$ with an incubation time of $30 \mathrm{~min}$ in a repeated batch process. Biomass equivalent to $36 \mathrm{mU}$ of tannase was incubated with $1 \mathrm{~mL}$ of $12.5 \mathrm{mM}$ methyl gallate. After each operation, CAT was centrifuged at $5000 \times g, 4{ }^{\circ} \mathrm{C}$ for $5 \mathrm{~min}$ and was then washed with $20 \mathrm{mM}$ of citrate-phosphate buffer $\mathrm{pH}$ 7.0. The resulting CAT was then subsequently used for another set of operations. Gallic acid production was determined for each batch.

\section{Authors' contributions}

Conceptualization and methodology, AK and CK; investigation AK, CK, SL, THN, DH, SK; supervision CK, SL, THN and DH; writing-original draft, review \& editing AK. All authors read and approved the final manuscript.

\section{Funding}

This research study was partially funded by the Thailand Research Fund through the Research Grant for New Scholar (MRG6280057) and the Bernd Rode Award 2019-ASEA Uninet scholarship granted by the OeAD-Austrian Agency for International Cooperation in Education \& Research. Lastly, this work was also supported by the Research Center for Multidisciplinary Approaches to Miang, Chiang Mai University. 
Availability of data and materials

Not applicable.

\section{Ethics approval and consent to participate}

Not applicable.

\section{Consent for publication}

Not applicable.

\section{Competing interests}

The authors declare that they have no conflict of interest.

\section{Author details}

${ }^{1}$ Division of Biochemistry and Biochemical Technology, Department of Chemistry, Faculty of Science, Chiang Mai University, Chiang Mai 50200, Thailand. ${ }^{2}$ Division of Biotechnology, Faculty of Agro-Industry, Chiang Mai University, Chiang Mai 50100, Thailand. ${ }^{3}$ Research Center for Multidisciplinary Approaches to Miang, Chiang Mai University, Chiang Mai 50200, Thailand. ${ }^{4}$ Department of Biology, Faculty of Science, Chiang Mai University, Chiang Mai 50200, Thailand. ${ }^{5}$ Food Biotechnology Laboratory, Faculty of Food Science and Technology, BOKU University of Natural Resources and Life Sciences, 1190 Vienna, Austria. ${ }^{6}$ Institute of Nutrition, Mahidol University, 999 Phutthamonthon 4 Rd., Nakhon Pathom 73170, Thailand.

Received: 12 October 2019 Accepted: 18 April 2020

Published online: 25 April 2020

\section{References}

1. Nowak R, Olech M, Nowacka N. Chapter 97-plant polyphenols as chemopreventive agents. In: Watson RR, Preedy VR, Zibadi S, editors. Polyphenols in human health and disease. San Diego: Academic Press; 2014. p. 1289-307.

2. Yin-Yin O, leva S. Gallic acid and gallic acid derivatives: effects on drug metabolizing enzymes. Cur Drug Metab. 2003:4:241-8.

3. Bajpai B, Patil S. A new approach to microbial production of gallic acid. Braz J Microbiol. 2008:39:708-11.

4. Jung $\mathrm{S}$, Choe JH, Kim B, Yun H, Kruk ZA, Jo C. Effect of dietary mixture of gallic acid and linoleic acid on antioxidative potential and quality of breast meat from broilers. Meat Sci. 2010:86:520-6.

5. Samuel KG, Wang J, Yue HY, Wu SG, Zhang HJ, Duan ZY, Qi GH. Effects of dietary gallic acid supplementation on performance, antioxidant status, and jejunum intestinal morphology in broiler chicks. Poult Sci. 2017;96:2768-75.

6. Borges A, Ferreira C, Saavedra MJ, Simões M. Antibacterial activity and mode of action of ferulic and gallic acids against pathogenic bacteria. Microb Drug Resist. 2013;19:256-65.

7. Sarjit A, Wang Y, Dykes GA. Antimicrobial activity of gallic acid against thermophilic Campylobacter is strain specific and associated with a loss of calcium ions. Food Microbiol. 2015;46:227-33.

8. Aoki K, Shinke R, Nishira H. Purification and some properties of yeast tannase. Agric Biol Chem. 1976:40:79-85.

9. Mahmoud AE, Fathy SA, Rashad MM, Ezz MK, Mohammed AT. Purification and characterization of a novel tannase produced by Kluyveromyces marxianus using olive pomace as solid support, and its promising role in gallic acid production. Int J Biol Macromol. 2018;107:2342-50.

10. Lekha PK, Lonsane BK. Production and application of tannin acyl hydrolase: state of the art. Adv Appl Microbiol. 1997:44:215-60.

11. Kanpiengjai A, Chui-Chai N, Chaikaew S, Khanongnuch C. Distribution of tannin-'tolerant yeasts isolated from Miang, a traditional fermented tea lea (Camellia sinensis var. assamica) in northern Thailand. Int J Food Microbiol. 2016;238:121-31.

12. Valduga E, Valério A, Treichel H, Furigo Júnior A, Di Luccio M. Optimization of the production of total carotenoids by Sporidiobolus salmonicolor (CBS 2636) using response surface technique. Food Bioprocess Technol. 2008;2:415.

13. Polburee P, Yongmanitchai W, Lertwattanasakul N, Ohashi T, Fujiyama K, Limtong S. Characterization of oleaginous yeasts accumulating high levels of lipid when cultivated in glycerol and their potential for lipid production from biodiesel-derived crude glycerol. Fungal Biol. 2015:119:1194-204.

14. Banerjee D, Pati BR. Optimization of tannase production by Aureobasidium pullulans DBS66. J Microbiol Biotechnol. 2007:17:1049-53.
15. Mondal KC, Banerjee R, Pati BR. Tannase production by Bacillus licheniformis. Biotechnol Lett. 2000;22:767-9.

16. Seth $M$, Chand S. Biosynthesis of tannase and hydrolysis of tannins to gallic acid by Aspergillus awamori_optimisation of process parameters. Process Biochem. 2000;36:39-44.

17. Elwan HAM, Elnesr SS, Abdallah Y, Hamdy A, El-Bogdady AH. Red yeast (Phaffia rhodozyma) as a source of Astaxanthin and its impacts on productive performance and physiological responses of poultry. Worlds Poult Sci J. 2019;75:273-84.

18. Tapingkae W, Panyachai K, Yachai M, Doan HV. Effects of dietary red yeast (Sporidiobolus pararoseus) on production performance and egg quality of laying hens. J Anim Physiol Anim Nutr. 2018;102:e337-44.

19. Fathy SA, Mahmoud AE, Rashad MM, Ezz MK, Mohammed AT. Improving the nutritive value of olive pomace by solid state fermentation of Kluyveromyces marxianus with simultaneous production of gallic acid. Int J Recycl Org Waste Agric. 2018;7:135-41.

20. Rodriguez-Duran LV, Contreras-Esquivel JC, Rodriguez R, Prado-Barragan LA, Aguilar CN. Optimization of tannase production by Aspergillus niger in solidstate packed-bed bioreactor. J Microbiol Biotechnol. 2011;21:960-7.

21. Banerjee D, Mahapatra S, Pati BR. Gallic acid production by submerged fermentation of Aspergillus aculeatus DBF9. Res J Microbiol. 2007;2:462-8.

22. Belur PD, Mugeraya G, Subbalaxmi S. Studies on the extracellular tannase from newly isolated Bacillus thurangiences BN2. In: Lee K editors. Chemical, Biological and Environmental Engineering. 2009. p. 379-84.

23. Treviňo L, Contreras-Esquivel JC, Rodríguez-Herrera R, Aguilar CN. Effects of polyurethane matrices on fungal tannase and gallic acid production under solid state culture. J Zhejiang Univ Sci B. 2007:8:771-6.

24. Aguilar-Zárate P, Cruz MA, Montañez J, Rodríguez-Herrera R, Wong-Paz JE, Belmares RE, Aguilar CN. Gallic acid production under anaerobic submerged fermentation by two bacilli strains. Microb Cell Fact. 2015;14:209.

25. Belur PD, Gopal M, Nirmala KR, Basavaraj N. Production of novel cell-associated tannase from newly isolated Serratia ficaria DTC. J Microbiol Biotechnol. 2010;20:732-6

26. Belur P, Mugeraya G, Kuppalu N. Temperature and pH stability of a novel cell-associated tannase of Serratia ficaria DTC. Int J Biotechnol Biochem. 2010:6:667-74.

27. Belur PD, Goud R, Goudar DC. Optimization of culture medium for novel cell-associated tannase production from Bacillus massiliensis using response surface methodology. J Microbiol Biotechnol. 2012;22:199-206.

28. Palabhanvi B, Belur PD. Enhancing gallic acid content in green tea extract by using novel cell-associated tannase of Bacillus massiliensis. J Food Biochem. 2013:37:528-35.

29. Yao J, Guo GS, Ren GH, Liu YH. Production, characterization and applications of tannase. J Mol Catal B Enzym. 2014;101:137-47.

30. Aharwar A, Parihar DK. Tannases: production, properties, applications. Biocatal Agric Biotechnol. 2018;15:322-34.

31. Kanpiengjai A, Unban K, Nguyen T-H, Haltrich D, Khanongnuch C. Expression and biochemical characterization of a new alkaline tannase from Lactobacillus pentosus. Protein Expr Purif. 2019:157:36-41.

32. Mohamad NR, Marzuki NHC, Buang NA, Huyop F, Wahab RA. An overview of technologies for immobilization of enzymes and surface analysis techniques for immobilized enzymes. Biotechnol Biotechnol Equip. 2015:29:205-20.

33. Kirkpinar F, Basmacioğlu H. Effects of pelleting temperature of phytase supplemented broiler feed on tibia mineralization, calcium and phosphorus content of serum and performance. Czech J Anim Sci. 2006;51:78-84

34. Sharma S, Bhat TK, Dawra RK. A Spectrophotometric method for assay of tannase using rhodanine. Anal Biochem. 2000;279:85-9.

35. Saenge C, Cheirsilp B, Suksaroge TT, Bourtoom T. Efficient concomitant production of lipids and carotenoids by oleaginous red yeast Rhodotorula glutinis cultured in palm oil mill effluent and application of lipids for biodiesel production. Biotechnol Bioprocess Eng. 2011;16:23-33.

\section{Publisher's Note}

Springer Nature remains neutral with regard to jurisdictional claims in published maps and institutional affiliations. 